\title{
Institutional conditions and social innovations in emerging economies: insights from Mexican enterprises' initiatives for protecting/preventing the effect of violent events
}

\author{
Maribel Guerrero ${ }^{1,2} \cdot$ David Urbano ${ }^{3}$
}

Published online: 21 March 2020

(c) The Author(s) 2020

\begin{abstract}
Latin-American countries are characterised by societal problems like violence, crime, corruption, the informality that influence any entrepreneurial activity developed by individuals/organisations. Social innovations literature confront "wicked problems" with strong interdependencies among different systems/actors. Yet, little is known about how firms use innovation to hedge against economic, political or societal uncertainties (i.e., violence, social movements, democratisation, pandemic). By translating social innovation and institutional theory approaches, this study analyses the influence of formal institutions (government programs and actions) and informal institutions (corruption, extortion and informal trade) on the development/implementation of enterprises' technological initiatives for protecting/preventing of victimisation. By using data from 5525 establishments interviewed in the 2012/2014 National Victimisation Survey of the Mexican National Institute of Statistics and Geography (INEGI), our findings shows that formal conditions (government programs) and informal conditions (corruption, extortion and informal trade) are associated with an increment in the number of enterprises' social innovations. Our findings also contribute to the debate about institutional conditions, social innovations, and the role of ecosystems' actors in developing economies. A provoking discussion and implications for researchers, managers and policymakers emerge from this study.
\end{abstract}

Keywords Institutional approach · Social innovations · Enterprises · Emerging economies · Mexico

JEL Classification $\mathrm{K} 22 \cdot \mathrm{K} 42 \cdot \mathrm{M} 21 \cdot \mathrm{O} 35 \cdot \mathrm{O} 43 \cdot \mathrm{O} 54$

Maribel Guerrero

maribel.guerrero@northumbria.ac.uk

David Urbano

david.urbano@uab.cat

1 School of Business and Economics, Universidad del Desarrollo, Av. Plaza 680, San Carlos de Apoquindo, Las Condes, Chile

2 Business and Law Faculty, Newcastle Business School, Sutherland Building, 2 Ellison Pl, Newcastle upon Tyne, UK

3 Department of Business and Centre for Entrepreneurship and Social Innovation Research (CREIS), Universitat Autònoma de Barcelona, Cerdanyola del Vallés, Barcelona, Spain 


\section{Introduction}

The accumulation of knowledge related to innovation and technology transfer literature has been focused on the effectiveness of policies that promotes entrepreneurial innovations (Meissner et al. 2017; Guerrero and Urbano 2019), as well as the influence of these policies on the enterprises' strategies for capturing innovation performance (Scuotto et al. 2017; Guerrero et al. 2019; Link and Scott 2019). However, little is known about how firms use innovation to hedge against economic uncertainties (Demircioglu and Audretsch 2018; Goel and Nelson 2020), or the current political/societal uncertainties (i.e., violence, social movements, democratisation, pandemic). Inspired by this research gap, this research explores the links between institutional conditions and enterprises' (technological) actions to respond to societal uncertainties that are affecting their business activities/performance (i.e., violent events and crime).

The difference related to social entrepreneurship ${ }^{1}$ is that social innovations refer to the process of developing/implementing novel solutions to social problems by individuals or organisations. The assumption is that social innovations entail an institutional change to confront "wicked problems" (Rittel and Webber 1973) with strong interdependencies among multiple systems/actors (Rayner 2006). An ongoing academic debate is how "wicked problems" (i.e., violence, crime, extortion, corruption, informality and social mobilisations) are affecting any entrepreneurial and innovative activity developed by individuals/organisations in emerging economies (Hoskisson et al. 2000; Lee et al. 2015; Subramaniam et al. 2015). The recognition of societal problems provides threats/opportunities for new/established entrepreneurs (Howard-Grenville et al. 2014). For this reason, it is relevant to understand how individuals/organisations develop/implement alternatives to reduce/prevent the effect of socio-economic problematics on their entrepreneurial activities (Greenwood et al. 2011; Schweitzer et al. 2015).

Extant literature on institutional research has played a significant role in the understanding of social innovations (Battilana and Dorado 2010; Lawrence et al. 2002; Zietsma and Lawrence 2010). Similarly, entrepreneurship literature has also recognised the growing importance in the analysis of emerging/developing economies, the relevance of understanding the strengths/weaknesses of institutions, and an increasing necessity to explore these issues with robust theoretical approaches such as institutional theory (Wright et al. 2005). According to Messner et al. (2013), institutions influence how social life is regulated and facilitate the functioning of social systems. Therefore, to the study, the influence of societal problems (as crime) demands a better understanding of the institutional structure, the institutional regulation, and the institutional performance. In this perspective, institutions - those who establish the "rules of the game"-significantly shape organisational strategies and individual decisions (North 1990; Peng 2001, 2003).

Each society has multiple groups with different opinions explained by constraining norms, values, and beliefs (Webb et al. 2009, p. 3). Because of these differences, a gap often exists between what certain groups understand to be legal (specified by laws and regulations) and what they consider to be legitimate (specified by norms, values, and beliefs) (Baumol 1990; Dowling and Pfeffer 1975; Scott 1995; Weber 1978). This gap is more relevant in developing economies by the variance between what is legal in those societies

\footnotetext{
1 Social entrepreneurship is focused on individuals/organisations who create innovative initiatives, build new social arrangements, and mobilize resources in response to collective social problems rather than market criteria (Alvord et al. 2004).
} 
and what some groups consider to be legitimate in those societies allows for certain dark conditions to emerge (Webb et al. 2009). Translating this reasoning into social innovation and adopting North's ideas (1990), enterprises' social innovations may be configured by the quality of formal institutions (regulations, programs) and the quality of informal institutions (values, attitudes). If these conditions are not optimal, individuals or organisations assume that they are competent interpreters of their own lives and competent solvers of their problems (Griffin and Prakash 2014). As a result, they develop/implement effective methods for cultivating social innovation as a mechanism of prevention or protection of violent events in developing economies.

This study analyses the influence of formal institutions (government programs and actions) and informal institutions (corruption, extortion and informal trade) on the development/implementation of enterprises' technological initiatives for protecting/preventing of victimisation. By adopting the institutional approach (North 1990; Scott 1995; Weber 1978), we proposed a conceptual framework tested in a Latin-American country-Mexico-. Why? Because this country has implemented several public initiatives for transiting into the innovative-driven economy but with a retard related to social issues. This scenario is adequate for analysing how the lack of quality of institutions generate negative externalities for individuals and organisations. By using data from 5525 establishments interviewed in the 2012/2014 National Victimisation Survey of the Mexican National Institute of Statistics and Geography (INEGI), our findings shows that formal conditions (government programs) and informal conditions (corruption, extortion and informal trade) are associated with an increment in the number of enterprises' social innovations. A provoking discussion and implications for researchers, managers and policymakers emerge from this study.

After this introduction, this paper is organised as follows. Section 2 presents the literature review and our proposed conceptual model. Section 3 describes the methodological design. Section 4 outlines the results and discussion. Finally, Sect. 5 summarises the concluding remarks, limitations, implications, and avenues for further research.

\section{Theoretical framework}

\subsection{Formal conditions and enterprises' social innovations}

Government intervention aligns quality of life (economic, political, and cultural) and social behaviours (i.e., criminal activity). In emerging economies, government intervention implies the combination of programs to foster economic growth and programs to reduce criminal and violent events. On the economic point of view, government intervention is oriented toward attracting private capital (Coleman et al. 2005). However, criminal/violent events represent many costs for developing economies (Edwards 2001). On the violence/ crime perspective, government intervention requires an understanding of violent/criminal event and the available resources (Coleman 2003; Byrne and Marx 2011). If the quality of institutions is not right, governmental programs will be predominantly reactive since their implementation until their effectiveness (Bunker 2013). The timing and socioeconomic conditions will produce a negative effect on enterprises' operations/performance (Okereke et al. 2012). Given the reactive and retarded governmental intervention, enterprises will implement strategies to protect theirs operations and employees from adverse societal conditions (Mair and Marti 2009; Marti et al. 2013; Van Wijk et al. 2015). By assuming the lack of institutional quality, we propose the following hypotheses: 
H1 The existence of reactive governmental programs increase the number of social innovations developed by enterprises to address societal problematics.

H1a The effect of reactive governmental programs on the number of social innovations will be positively reinforced when enterprises have been victimised.

A pro-active government intervention requires a fundamental change in individuals' attitudes/willingness to reduce the vulnerabilities generated by criminal or violent individuals/ organisations (Vaccaro and Palazzo 2015; Williams and Godson 2002). Previous studies provide little insights into the effectiveness of anti-crime actions/strategies on the reduction of criminal/violent events. In the 1990s, U.S. federal resources were allocated into police departments to implement initiatives (i.e., an increment in the number of police or the use of technology) without any results (Levitt 2004). Aggressive tacit strategies (i.e., aggressive panhandling, community policing rather than merely responding to emergency calls) were implemented in large cities to prevent criminal events (Corman and Mocan 2002). As a result, New York and Boston evidenced a reduction of violence (Levitt 2004). We assume that the implementation of proactive government interventions will be challenging when the lack of quality of institutions is persisting (Coleman et al. 2005). Consequently, the effects produced by proactive initiatives will be few. In this assumption, enterprises will development/implement social innovations as protection or prevention mechanism of adverse events. Based on these arguments, we propose the following hypotheses:

H2 The existence of reactive governmental actions reduce the number of social innovations developed by enterprises to address societal problematics.

H2a The effect of reactive governmental actions on the number of social innovations will be positively reinforced when enterprises have been victimised.

\subsection{Informal conditions and enterprises' social innovations}

According to Aidis (2005), corruption is one of the most relevant informal barriers to developing any entrepreneurial initiative. Previous studies found that countries with lower entry barriers and less corruption are associated with the highest level of entrepreneurial initiatives (Klapper et al. 2010). However, recent studies also found that corruption can be beneficial for those individuals/organisations involved in entrepreneurial activities with well-established networks and sufficient financial resources (Méon and Sekkat 2005). Therefore, corruption plays a dual role, serving as both grease and sand for entrepreneurship (Chowdhury et al. 2015). In this regard, Rodriguez et al. (2005) explain that substantial literature reveals two dimensions of corruption across countries: (1) the pervasive that reveals the average firm's likelihood of encountering corruption in its regular interactions with state officials; and (2) the arbitrary that results from the ability and willingness of corrupt officials to vary the set of necessary approvals to extract maximum bribes or from the entry of bureaucrats into the market for extortion. In both cases, the principals (authorities or third persons) are interested in maximising their return, while the agents (individuals/organisations) might be motivated by their interests and strategies (Wu 2005). We assume that enterprises need to explore diverse alternatives to address societal problematics. Therefore, managers/owners who accept to participate in the act of corruption motivated by an authority (police, public persecutor) 
does not guaranty the reduction of criminal events (De Bakker et al. 2005; Egri and Ralston 2008; Griffin and Prakash 2014). Based on these arguments, we propose the following hypotheses:

H3 Corruption increases the number of social innovations developed by enterprises to address societal problematics.

H3a The effect of corruption on the number of social innovations will be positively reinforced when enterprises have been victimised.

Previous studies suggest that extortion is a significant hindrance for establishments in developing economies (Mehlum et al. 2002; Morselli and Giguere 2006; Ranasinghe 2012). According to Ranasinghe (2012), extortion is an essential channel for understanding resource misallocation. In this vein, criminal organisation approaches potential victims (entrepreneurs) and demands a payment (extortion, tribute/fees), where failure to comply can result in physical harm or damage to property (Morselli and Giguere 2006). The dimension of extortions will depend on the victims' ability to pay the fee. A higher violent capacity increases both the supply and the demand for protection, as well as increasing both the price of protection and the incomes of violent groups (Mehlum et al. 2002). In the market-based extortion, we assume that a rise in violent capacity creates a higher demand/ price for protection. Therefore, disorder and violence increase the willingness to pay for protection and increase the rents to be collected by criminal organisations. Victimised enterprises will be more likely to implement technological strategies as a mechanism of protection (Levitt 2004). Based on these arguments, we propose the following hypotheses:

H4 The extortion increases the number of social innovations developed by enterprises to address societal problematics.

H4a The effect of extortion on the number of social innovations will be positively reinforced when enterprises have been victimised.

A broader shadow economy is related to less tax revenue and less investment in public infrastructure (Loayza 1996). According to Nichter and Goldmark (2009, p. 1455), informal trade is related to unregistered enterprises with income from both legal and illegal goods/services. Bruton et al. (2012) consider that informal trade includes organisations of any size (not just small ones) that decide to do not to register. Therefore, in an informal economy, the exploration/exploitation of opportunities occur outside of formal institutional boundaries but within informal institutional boundaries (Webb et al. 2009; Zimmerman and Zeitz 2002). Under these conditions, enterprises face informal competitors with more competitive advantages (i.e., in terms of costs). These conditions hurt entrepreneurial activities with an intensified effect when enterprises have been victimised by organised crime (Gould Ellen and O'Regan 2008). We assume that enterprises are more likely to implement social innovations that allow them to protect their daily activities and prevent the effect on the performance of violent events. Based on these arguments, we propose the following hypotheses:

H5 Informal trade increases the number of social innovations developed by enterprises to address societal problematics. 


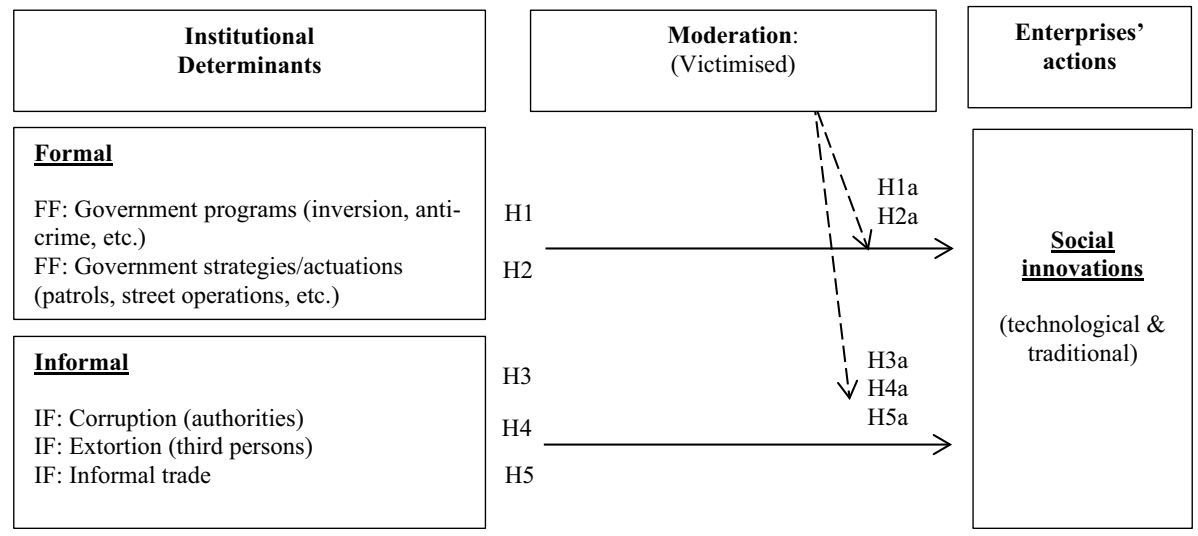

Fig. 1 Institutional determinants of enterprises' social innovations Source: Authors

H5a The effect of informal trade on the number of social innovations will be positively reinforced when enterprises have been victimised.

\subsection{Proposed conceptual framework}

Figure 1 shows the proposed conceptual framework to understand the influence of formal institutions and informal institutions on the development/implementation of enterprises' technological initiatives for protecting/preventing of victimisation. By adopting the institutional approach (North 1990; Scott 1995; Weber 1978), we argue the effect of specific formal (government programs and government actions) and informal (corruption, extortion and informal trade) institutional environmental conditions. Given the highest rate of victimisation in emerging economies, we included as a moderation the effect generated when the enterprise has faced an offence from violent/criminal organisations (Levitt 2004).

\section{Methodology}

\subsection{Research setting}

Officially called the United Mexican States, Mexico is a federal republic comprising of 32 states with a total population of more than 122 million. Politically, Mexico faced a process of political transition from a one-party system that had dominated for 70 years under the Partido Revolucionario Institucional (PRI) to a multiparty system in 2000 (Bunker 2013). Mexico had two Partido Acción Nacional (PAN) administrations, under Fox (2000-2006) and Calderón (2007-2012). A return of the PRI during the Peña Nieto administration (2013-2018). In the last election, a new democratic party with the Lopez Obrador administration (2018-2023). Economically, Mexico has been classified as an efficiency-driven (Porter and Schwab 2008, p. 9). It means that the country's main advantage comes from producing more advanced products and services highly efficiently. However, the main challenges have been the lack of capacity to produce innovative products/services using the most advanced methods (Solleiro and Castañón 2005). The GDP has shown a higher 
growth rate in comparison with other Latin-American emerging economies. Regarding the openness to international trade, Mexico has celebrated more than 40 free trade agreements with different countries around the world (Mexican Government 2013, p. 23). Socially, the growing criminal organisations increased the violence/crime levels within Mexico (Kan 2011). However, the levels of violence in Mexico have been lower than Honduras, Venezuela, Belize, Salvador, Guatemala, Colombia, Brazil and Dominican Republic (Heinle et al. 2015, p. 2). Several weaknesses continue affecting the country in terms of a rigid labour market, a weak educational system, an inequitable income distribution, social tensions, rampant crime, low levels of trust in politicians, and a sense of rigid reforms (Hausmann et al. 2009).

Social, economic and democratic contrasts are aligned with two relevant trends. Firstly, adequate institutions reinforce that creative individuals/organisations would be more likely to create wealth via entrepreneurial activities (Sobel 2008). However, inadequate institutions produce that creative individuals/organisations would be involved in unproductive activities such as crime or specific negative behaviour (Rosenthal and Ross 2010). Secondly, in scenarios where national strategies abound to support economic growth and no comparable strategies at the national level exist to support social innovation, individuals/ organisations are motivated by the lack of quality of the institutions to develop innovative actions to solve the socio-economic problems that they faced (Mulgan 2006). Based on these arguments, this study analyses in-depth the institutional determinants of social innovations developed by Mexican enterprises.

\subsection{Sample and data collection}

The dataset used contains establishment-level ${ }^{2}$ data from the 2012 and the 2014 National Victimisation Survey. ${ }^{3}$ This database was collected by the Mexican National Institute of Statistics and Geography (INEGI). The sample was characterised as probabilistic and stratified as the results of the survey were widespread, including the entire study population, and possible measuring errors of estimates were also obtained (INEGI 2012). The survey yielded national estimates for the 32 Mexican states. In total, 51,804 establishments answered the $2012(23,635)$ and $2014(28,179)$ survey. Given the nature of our study, this sample suffered some reductions by the missing values in our main dependent variables. More concretely, only $10 \%$ of the establishments reported information about practices/ costs associated with the social innovations implemented to address the societal problems. Our final sample includes 5525 establishments.

\footnotetext{
${ }^{2}$ Establishment is defined as the collection of economic units that perform some economic activity in the country captured in the Economic Census, except for the activities related to agriculture and the public sector and government. These economic units are a single physical location, nestled in a place permanent and enclosed by buildings and facilities so fixed that it combines actions and resources under the control of a single owner entity or controller, mainly for processing activities, assembly, etc.

3 It was a common practice implemented in countries such as the United States to monitor the crime rates by a national representative survey across the population (Levitt 2004). In the case of Mexico, the 2012 survey captures the last year of the Felipe Calderón administration, and the 2014 survey captures the second year of the Peña Nieto administration.
} 


\subsection{Description of variables}

Based on previous empirical studies (Audretsch and Feldman 1996; Levitt 2004; Mauro 1998), we used three dependent variables to capture our proxy of social innovations. The sum_socialinn that is measured by the total number of innovations developed by the enterprises to address the societal problems. The sum_socialinntech that represents the number of technology social innovations (i.e., Global Positioning System -GPS-, protection systems cyberattacks, and creation of a security area/department), and the variable sum_socialinntrad that represents the number of traditional social innovations (i.e., change of locks/ doors, build gates and fences, change the location, and insurance). The InCost_socialinn measured by the natural logarithm of the total investment on social innovations expressed in Mexican Pesos.

The explanatory variables were associated with institutional environmental conditions. Using dichotomous variables, we built some proxies to explore both formal and informal conditions (see Table 1). First, formal factors were measured by the programs as well as the actions implemented by the government. Concerning government programs, we used three formal binary conditions that take value 1 when the interviewed have perceived the existence of (1) programs oriented toward attracting inversion; (2) programs oriented toward sensitisation; and (3) programs oriented toward anti-crime activities (Coleman et al. 2005; Smallbone and Welter 2006; Welter and Smallbone 2011). Regarding the actions implemented by the government, we used several binary variables to capture the existence of government strategies such as more patrols, video surveillance, maintenance, street lighting, and street operations (Levitt 2004). Second, informal factors were explored by corruption, extortion, and business informality measured by binary variables that take value 1 when the interviewed have manifested those practices and 0 otherwise. Regarding corruption, we used several modalities of corruption associated to public authorities such as the police, public prosecutor, and Army (Duyne 1996; Chowdhury et al. 2015; Méon and Sekkat 2005; Peng 2001, 2003). Regarding extortion, these conditions were based on extortion or the tribute or fee required by third persons (Morselli and Giguere 2006; Ranasinghe 2012; Ruggiero2010). Concerning informal trade, we used a binary variable that captures if the enterprises recognised informal trade in their regions (DiMaggio and Powell 1983; Webb et al. 2009). The moderator was associated with a dummy that captures if the establishment has or have not been victimised (Levitt 2004).

This study controlled specific structural characteristics of the establishment level (INEGI 2012). The enterprises' size was measured with categorical variables based on the number of employees (0-10 employees, 11-50 employees, 51-250 employees, and more than 250 employees). We used the group of more than 250 employees as a reference given their characteristics and resource availability to develop these strategies (Parker 2011). The enterprises' sector was measured by generic sectoral categories (services, industrial, and commercial) and using industrial as a reference group (Chowdhury et al. 2015). The technological profile was controlled using a binary variable that takes a value of 1 when the establishment was involved in technological sectors (Agarwal et al. 2010). Additionally, we controlled contextual characteristics including the State where the establishment is located (Meyer et al. 2009), and a dummy variable to control the level of distrust perceived by the establishment (Wu 2005). 


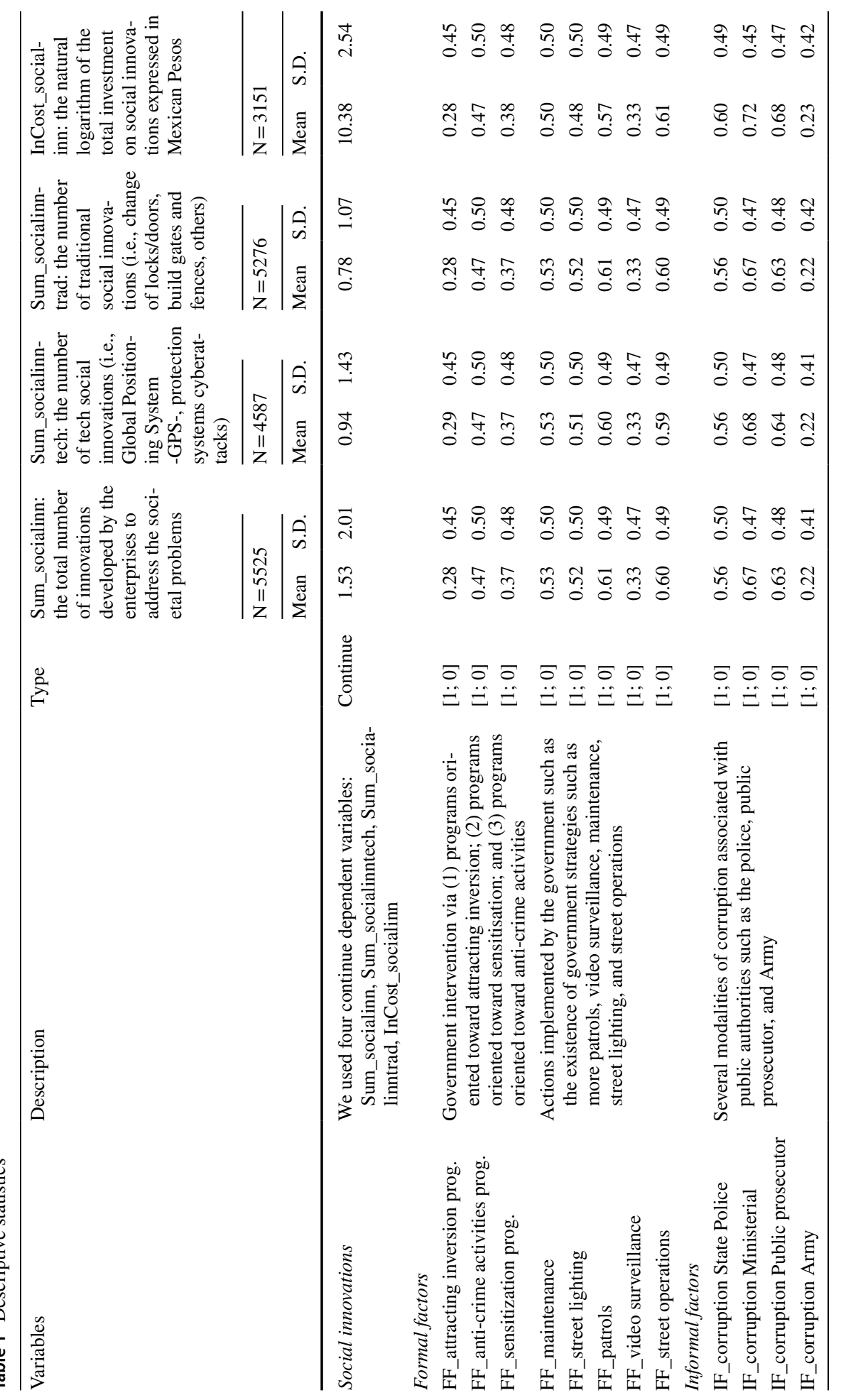




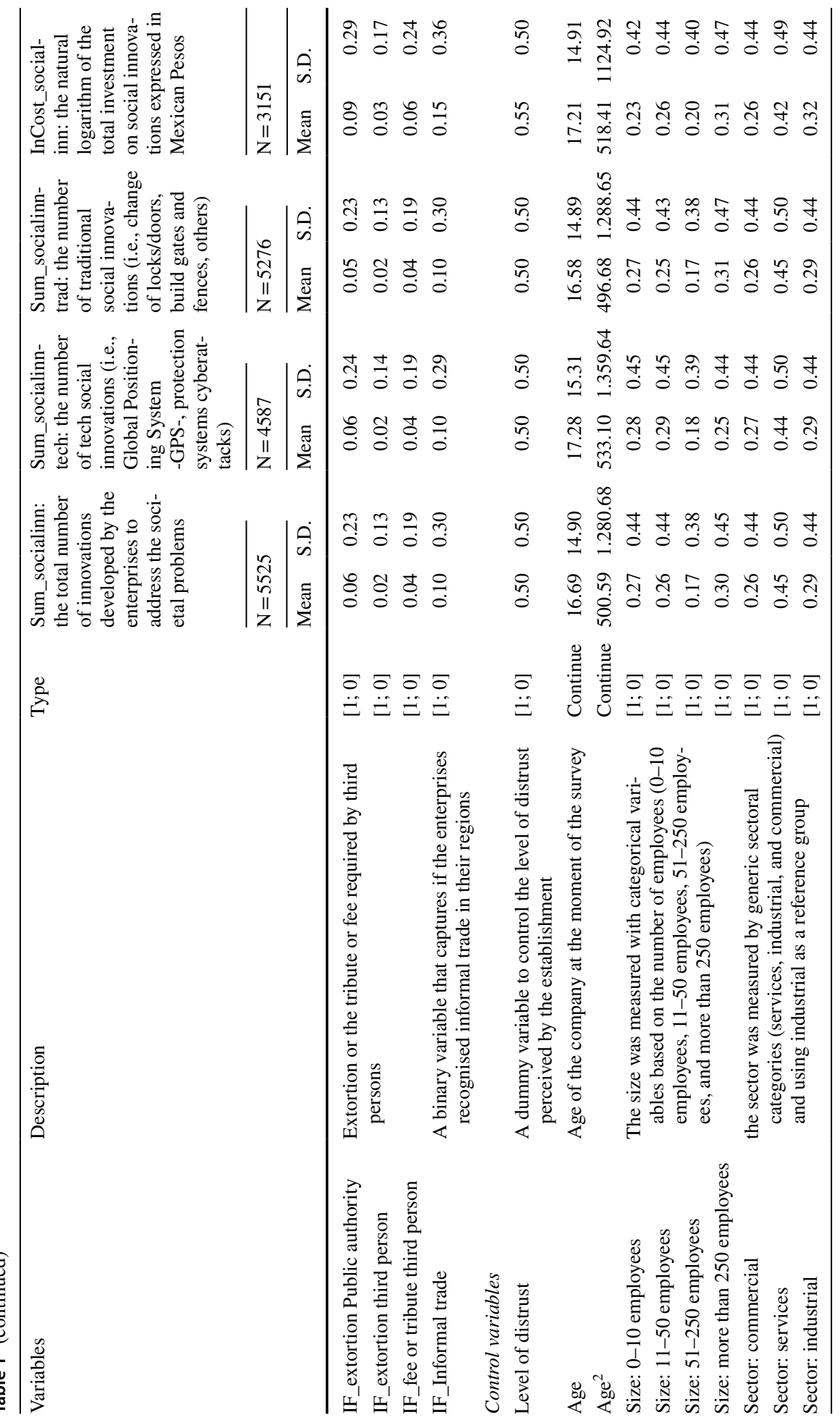









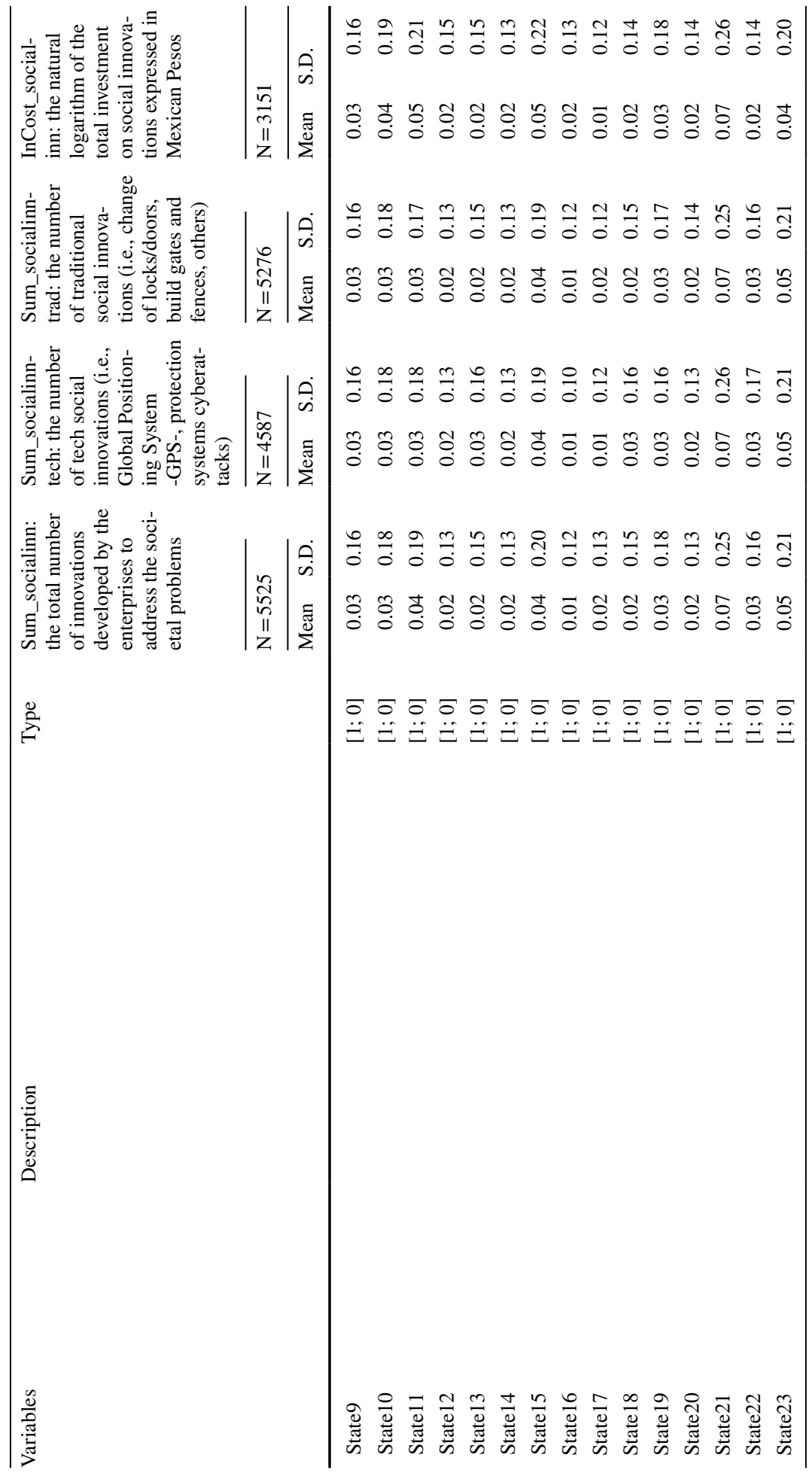









\subsection{Data analysis}

We used an ordinary-least-squares (OLS). OLS is a generalised modelling technique applied with multiple explanatory variables and also categorical explanatory variables that have been appropriately coded (Greene 2003). The general model estimated was: $\mathrm{Y}=\alpha+\beta_{1} \mathrm{X}_{1}+\beta_{2} \mathrm{X}_{2}+\varepsilon$; where, $\mathrm{Y}=$ enterprises' social innovation; $\mathrm{X}_{1}=$ formal institutional conditions; and $\mathrm{X}_{2}=$ informal institutional conditions. By adopting this model, we tested the explanatory variables on three models: Model 1 where the dependent variable was the total number of social innovations; Model 2 where the dependent variable was the number of technological (Model 2a) and traditional social innovations (Model 2b); and Model 3 where the dependent variable was the cost associated to those social innovations. The moderation effect of victimised was testing using two subsamples (non-victimised establishment and victimised establishment) in Model 1 and Model 3.

\section{Findings and discussion}

\subsection{Descriptive statistics}

Table 1 shows the descriptive statistics. During 2012/14, on average, the establishments interviewed developed 1.53 innovations to address the social problems arising from the lack of quality of institutions in their regions. More than $28 \%$ of the establishments interviewed recognised the existence of government programs, as well as identified some governmental actions to reduce social problems. However, more than $56 \%$ of the establishments perceived the corruption of police, ministerial, and public prosecutor. Moreover, almost $6 \%$ were extorted by public authorities and $2 \%$ by third persons. Thus, $4 \%$ of those establishments paid a fee or tribute to third persons. Regarding the structural characteristics, $27 \%$ of these establishments have less than ten employees, $26 \%$ from 11 to 50 employees, $17 \%$ from 51 to 250 employees, and $30 \%$ more than 250 employees. In average, these establishments have operated in the Mexican market for approximately 17 years. Moreover, $45 \%$ of the establishments developed an entrepreneurial activity associated with services (only $5 \%$ related to technological sectors).

Table 2 shows the correlation matrix that suggests low collinearity among the variables. The VIF was less than 2. It means that the standard error for the coefficient of that predictor variable is around two times as large as it. Therefore, the predictor variables were uncorrelated with the other predictor variables.

\subsection{Formal conditions and the development of enterprises' social innovations for protecting/preventing violent events}

Table 3 presents the regressions estimated for Models 1-3.

Regarding formal factors, all models show that the existence of government programs oriented to attract inversions and sensitisation increased the number of enterprises' social innovations to protect their entrepreneurial activities. Taking into account standardised coefficients, the effect of sensitisation programs $(0.067 ; p<0.001)$ is slightly higher than the effect of attracting inversions $(0.040 ; p<0.001)$. If we analyse the nature of the implemented measures, the effect of government programmes is higher when enterprises 


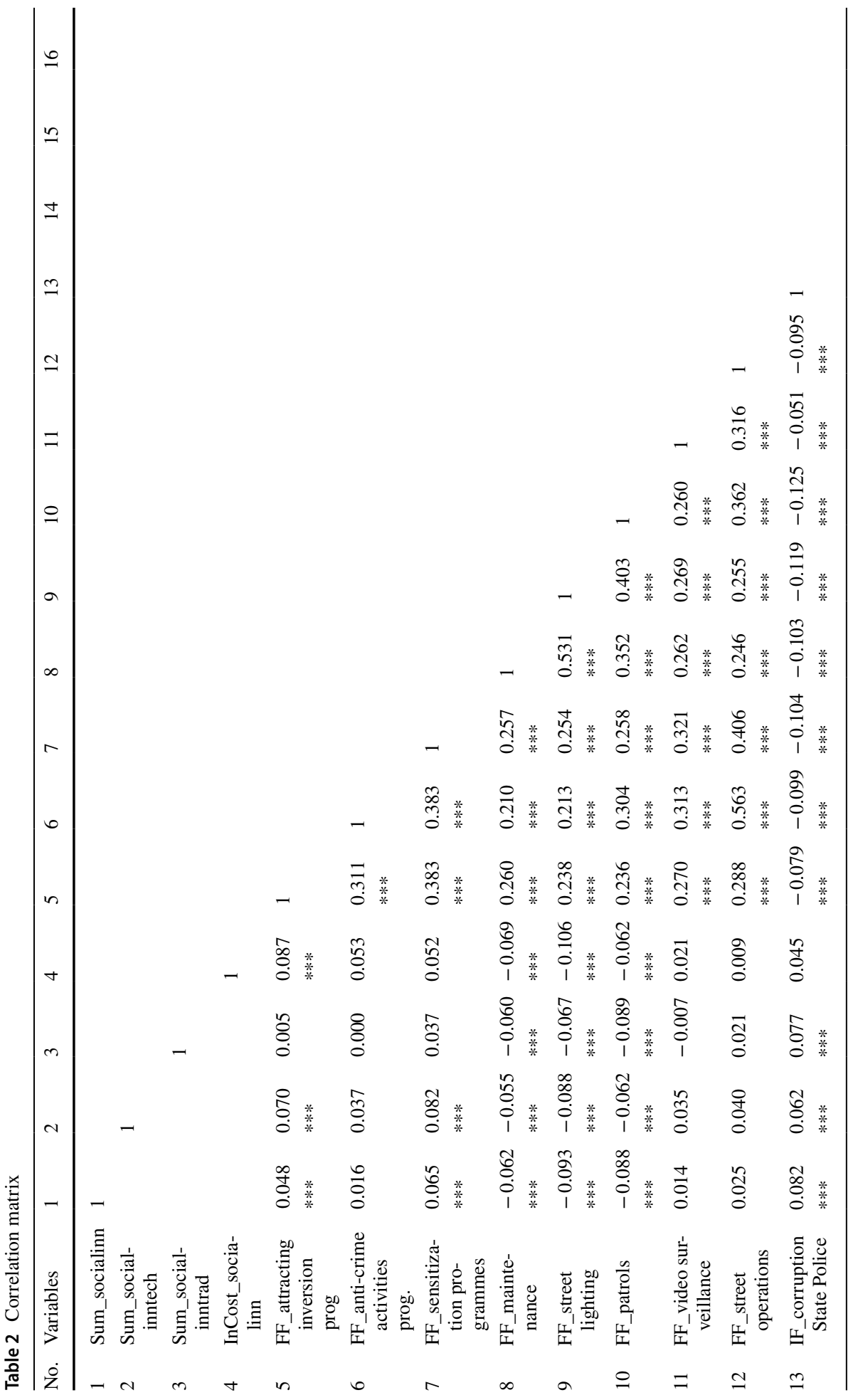




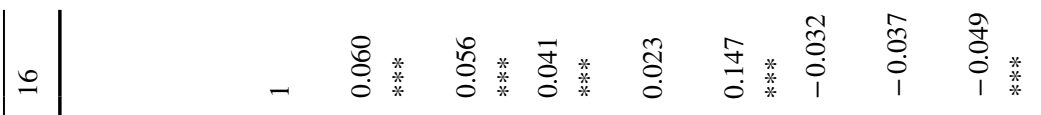

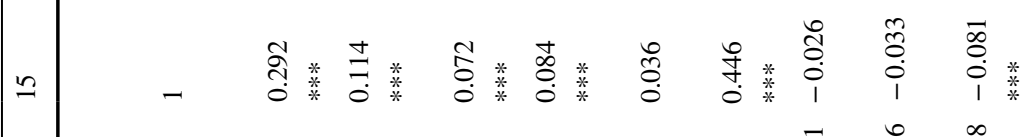

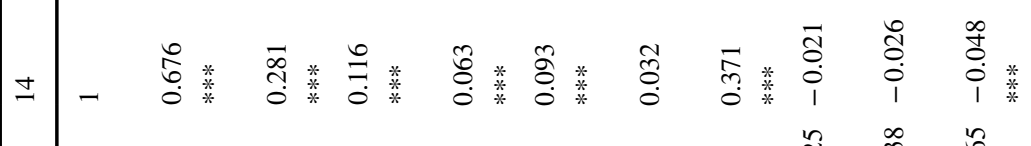

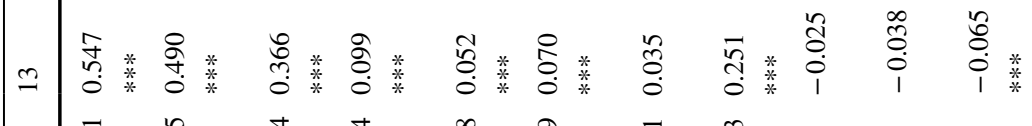



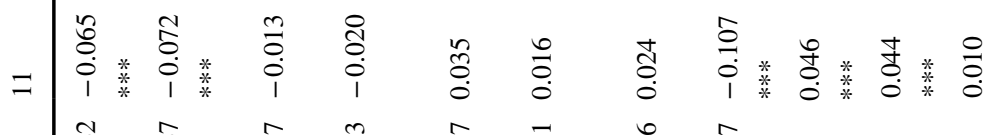

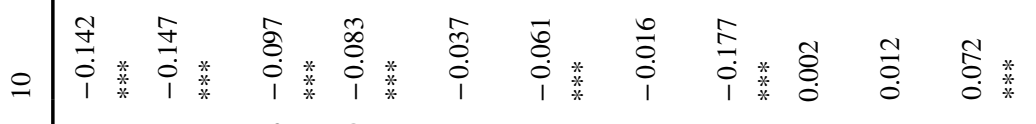

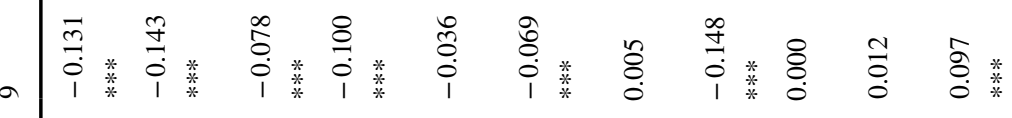

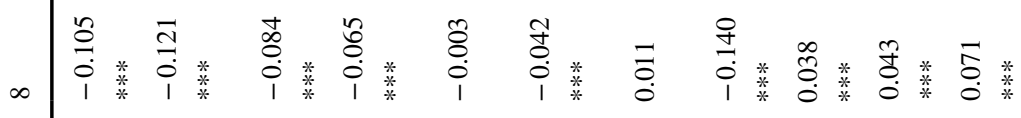

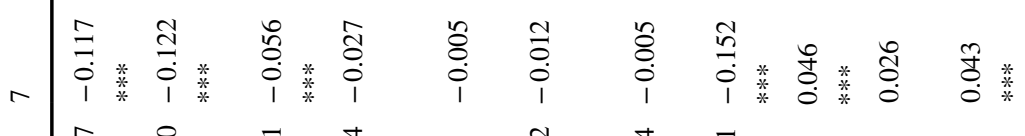

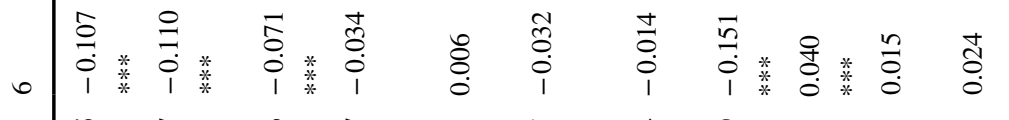

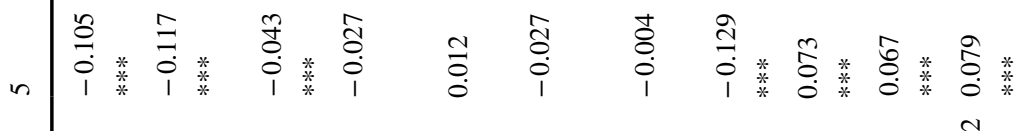

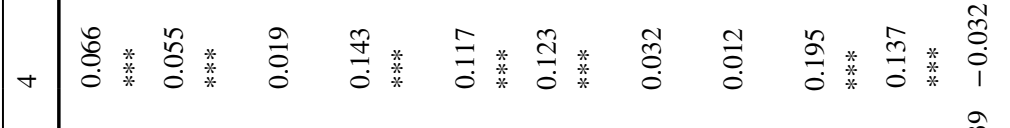

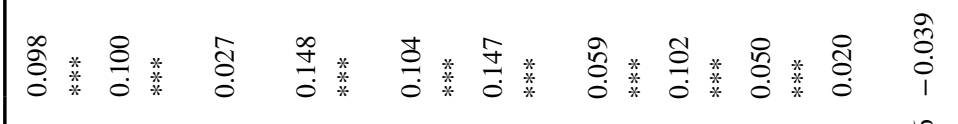

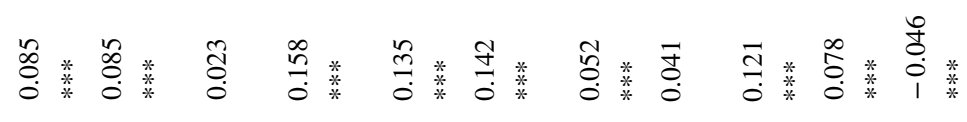
















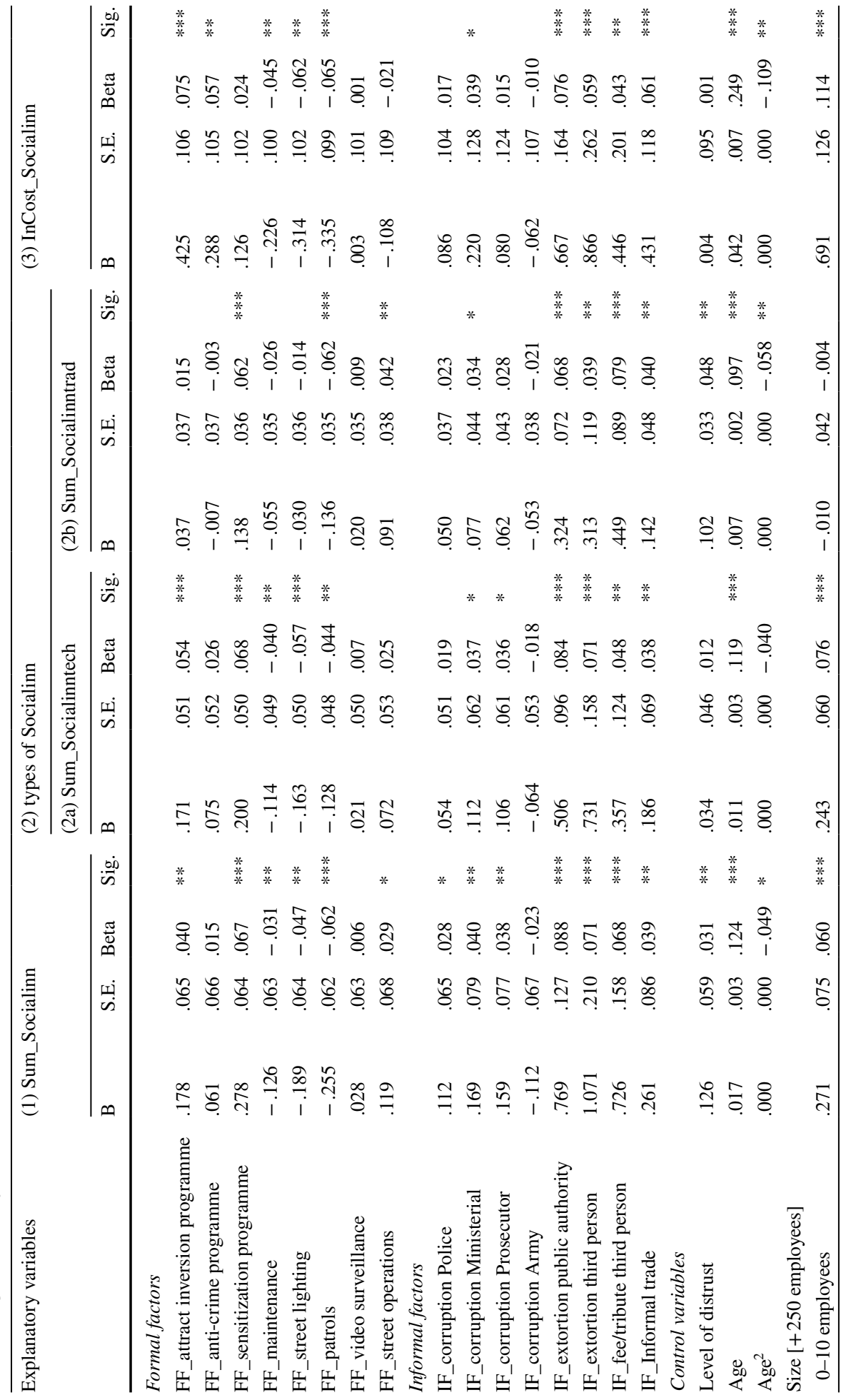




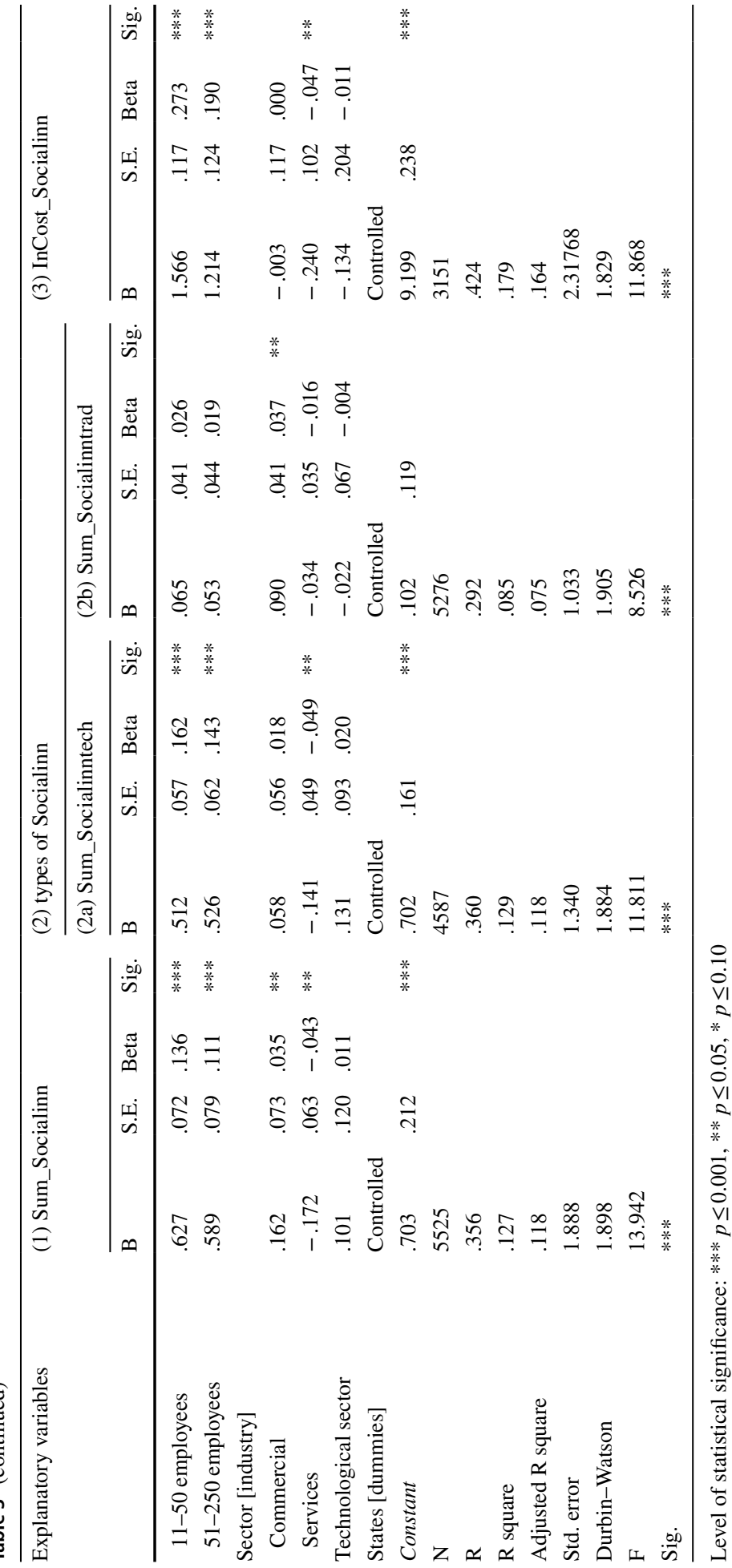


develop technological innovations as GPS or protection systems cyberattacks $(0.068$; $p<0.001$ for sensitisation, $0.054 ; p<0.001$ for attraction of inversions) than traditional social innovations as change of locks/doors, build gates/fences or change the location. On the other hand, The effect of anti-crime programs is significant when our dependent variable is associated with the cost of enterprises' social innovations (Model 3). Reactive government intervention increases the cost of social innovations $(0.057 ; p<0.050)$. In other words, enterprises tend to invest more money in both technological/traditional measures to address the societal problems that limited the daily development of their activities and security. These results are aligned to previous empirical studies that found that the existence of reactive governmental programs increases vulnerabilities that criminal individuals/ organisations seek to exploit (Bunker 2013; Coleman et al. 2005; Edwards 2001). Under these conditions, individuals/organisations transforming their perspective and looking for the preventing/protecting solutions that the institutions do not provide (Mair and Marti 2009; Marti et al. 2013; Van Wijk et al. 2015). However, not all enterprises have available resources/capabilities to implement this kind of initiatives. Less than $10 \%$ of the total sample have developed/implemented these initiatives. Although the survey's year showed lower levels of homicides (Kan 2011), criminal behaviours will be not eradicated only with reactive governmental programs. Therefore, these results support our $\mathrm{H} 1$.

Concerning government actions to reduce societal problems, our standardised coefficients show that the maintenance of actions $(-0.031 ; p<0.050)$, street lighting $(-0.047$; $p<0.050)$, and the increment of patrols $(-0.062 ; p<0.001)$ reduced the number of social innovations implemented by the Mexican enterprises (Model 1). Similar tendencies are observed in technological innovations (Model 2a) and investment in enterprises' innovations (Model 3). Mainly, the highest effect is produced by the existence of more patrols where the enterprises develop their economic activities. A plausible explanation is how the perception of real/tangible actions decreases the opportunity that creative people take advantage of the institutional weaknesses to generate unproductive or illegal activities. Even though the ambiguity of previous empirical studies, Levitt (2004) identify several practices adopted by governments that reduced societal problems such as crime and insecurity, specifically, authors conclude that more qualified police were associated with reductions in societal problems. Also, we did not find strong evidence on the effect of specific government actions such as the implementation of video surveillance and street operations to reduce insecurity problems. Our results are similar than the findings observed in U.S. cities by Corman and Mocan (2002) and Levitt (2004); where the implementation of technological initiatives produced few or null visible effects. In this sense, these results support our H2.

\subsection{Informal conditions and the development of enterprises' social innovations for protecting/preventing violent events}

Concerning informal factors, Model 1 shows the effect of diverse modalities of corruption on the number of social innovations implemented by the Mexican establishments during 2012 and 2014. Excluding the corruption linked to the Army because we did not find strong evidence, the standardised coefficients of corruption associated to Ministerial $(0.040 ; p<0.050)$ and public prosecutor $(0.038 ; p<0.050)$, whom represents the society judicially and ensure the respect of constitutional rights and guarantees, produced an increment in the number of enterprises' actions to protect their entrepreneurial activities. Particularly, Ministerial corruption evidences a higher effect on technological measures 
$(0.037 ; p<0.100)$ than traditional measures $(0.034 ; p<0.100)$, as well as on the cost associated to those measures $(0.039 ; p<0.100)$. In these scenarios, the evidence reveals that corruption is not beneficial for Mexican establishments (Méon and Sekkat 2005). By aligning extant empirical studies, corruption tends to be a barrier to entrepreneurial activity (Aidis 2005; Klapper et al. 2010). Following Rodriguez et al. (2005), our results may reveal a pervasive corruption in the interaction of enterprises with authorities but also with some shades of arbitrary from corrupt authorities to maximise their benefits. In this line, results support $\mathrm{H} 3$.

By contrasting our results, taking into account standardised coefficients, the number of total enterprises' social innovations $(0.088 ; p<0.001)$, both technological $(0.084$; $p<0.001)$ and traditional $(0.068 ; p<0.001)$, as well as in the expenditure linked to those innovations $(0.076 ; p<0.001)$ increased notably by the influence of extortion from authorities. Similar tendencies are observed in the case of extortions or tribute required by third persons. Results show that extortion is a major hindrance for any entrepreneurial activity because it is a channel for understanding resource misallocation (Mehlum et al. 2002; Morselli and Giguere 2006; Ranasinghe 2012). On the one hand, establishments paid attention to the demand for payments from authorities or third persons (Morselli and Giguere 2006). On the other hand, establishments also need to find innovative mechanisms of protection (Mehlum et al. 2002). The sustainability of these mechanisms will depend on the opportunity/cost and the allocation of resources (Ranasinghe 2012). Therefore, results support H4.

Our results also reveal the influence of informal trade on the number of social innovations of Mexican establishments $(0.039 ; p<0.050)$ and in the cost of those initiatives $(0.061 ; p<0.001)$. In the case of this explanatory variable, the effect that it produces by type is slightly higher in non-technological social innovation $(0.040 ; p<0.050)$ than technological $(0.038 ; p<0.050)$. In this case, establishments faced informal competitors with more competitive advantages in terms of costs because their exploitation of opportunities occurs within informal institutional boundaries (Webb et al. 2009; Zimmerman and Zeitz 2002). Usually, those informal boundaries are associated with regions with higher crime rates (Gould Ellen and O'Regan 2008). Therefore, formal enterprises are more oriented to ensure the development of their activities reinforcing alternatives to solve these social problematics. Therefore, our results support H5.

\subsection{Moderation effect of victimisation}

Table 4 shows the moderation effects of victimisation. Regarding formal environmental conditions, we observe on Model 1a and Model 3a that the effect of that governmental intervention (attraction of inversions and sensitisation) on the number of enterprises' social innovations is highest when enterprises have been victimised (supporting H1a). Similarly, Model 1a and Model 3a reveal that the effect of reactive governmental actions (patrols and maintenance) on the number of social innovations is reinforced when those enterprises have been victimised (supporting $\mathrm{H} 2 \mathrm{a}$ ).

Concerning informal environmental conditions, we only obtained evidence about the effect of public prosecutor corruption. Therefore, if we compare the standardised coefficients in Model 1 (Table 3) and Model 1a (Table 4), we suggest that the effect of corruption on the number of social innovations will be reinforced when those enterprises have been victimised (supporting H3a). Excepting fee/tribute to third persons, the variables associated to extortion (e.g., from authorities and third persons) evidenced that their effect on the number of social innovations is reinforced when those enterprises have not been 


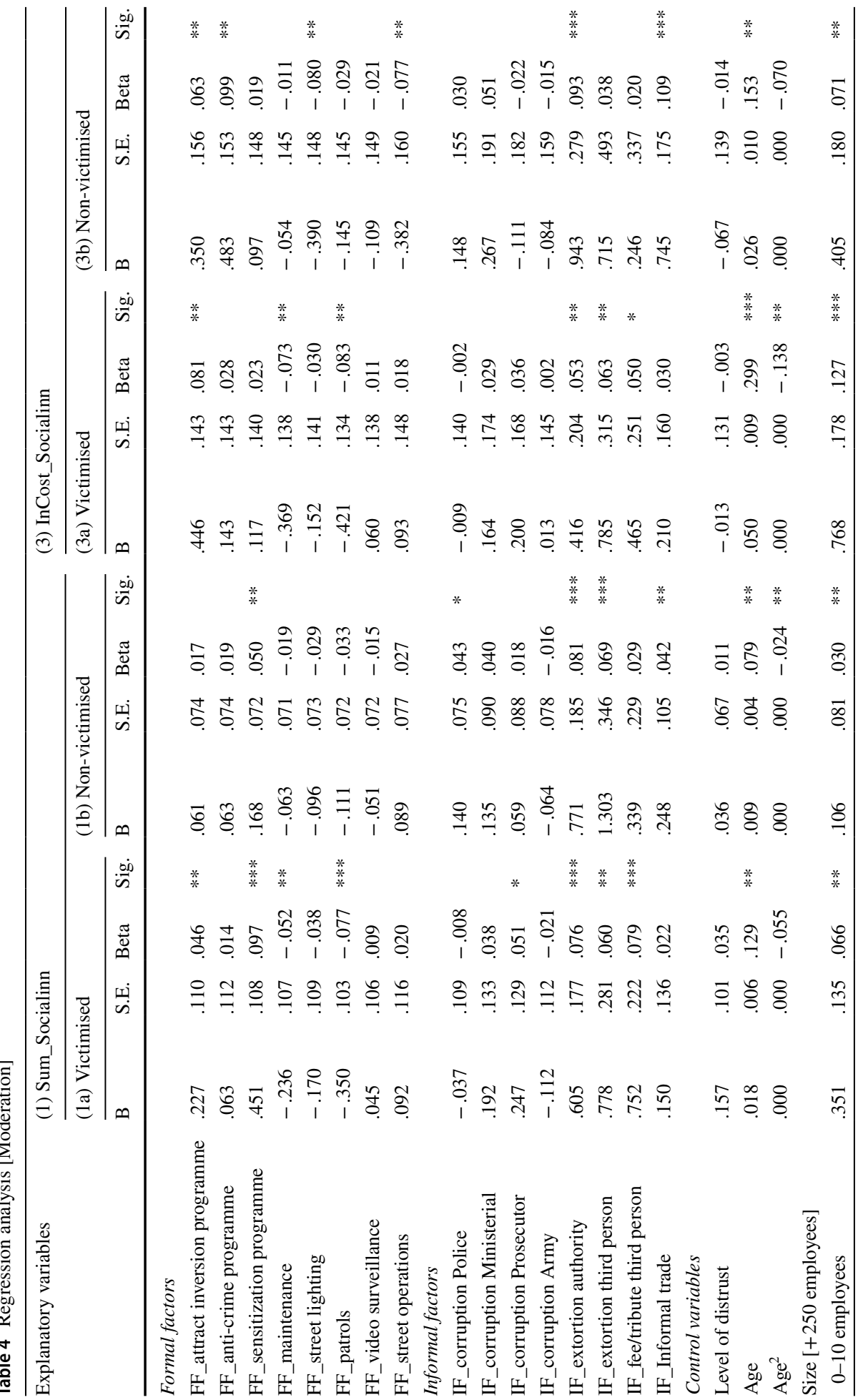







victimised (Model 1b and Model 3b). Therefore, we did not find strong evidence to support our H4a. In this vein, the effect of informal trade on the number of social innovations is reinforced when those enterprises have not been victimised (Model 1b and Model 3b). In this sense, we did not find strong evidence to support our H5a.

\section{Conclusions}

The study analysed the influence of formal institutions (government programs and actions) and informal institutions (corruption, extortion and informal trade) on the development/ implementation of enterprises' technological initiatives for protecting/preventing of victimisation. By testing our model using data from the National Victimisation Survey from the INEGI, we can extract three relevant conclusions. First, formal institutional conditions such as programs are associated with an increment in the number were social innovations. However, more tangible actions as patrols reduced the number of measures implemented by enterprises to address societal problems. The main reason could be the minor effect produced when the lack of quality of institutions does not solve the societal problems (Vaccaro and Palazzo 2015; Williams and Godson 2002). Second, informal environmental conditions have a substantial weight on the decision to implement social innovations. Nevertheless, we need to take into account that informal conditions (corruption, extortion and informal trade) are the mirror of formal conditions (government programs, laws, actions). It means that we are not able to disconnect both conditions because their transformations are closely related (North 1990). Third, victimisation reinforced the effect of certain informal/ formal conditions on social innovations. For victimised, the effect on the number of social innovations is reinforced in the case of formal conditions. However, the effects vary in the case of informal conditions.

Our study contributes to the literature by shedding some light on the linkages between technology transfer and social innovations developed by established enterprises for comprising certain formal/informal institutional conditions (Greenwood et al. 2011; HowardGrenville et al. 2014; Stenholm et al. 2013; Schweitzer et al. 2015), as well as participating in the debate on the roles of certain actors such enterprises and governments in developing economies (Griffin and Prakash 2014; Witkamp et al. 2011; Lee et al. 2015; Subramaniam et al. 2015). These insights are useful for the manager and policymakers to better address issues related to organisations and societies. For policymakers, this study exhibits key for$\mathrm{mal} /$ informal determinants of enterprises' social innovations. If policymakers expect a transition towards a more advanced economy is still required a change, evolution, and transformation the quality of institutions (educational system, labour market, security, and stable regulation, among others). Given the structural characteristic of institutions, it requires an active work in formal conditions to impact on the configuration of informal conditions and vice versa. For enterprise managers, this study offers insights about the mechanisms and practices for social innovation practices.

This study has several limitations that provide excellent opportunities for future research. The first limitation is the database used to analyse this phenomenon. Given the INEGI's confidentiality restrictions, we have access only to the data in its installations. In this sense, we did not have access to all variables, and their treatment/analysis was limited to the statistical resources available. Future studies could focus on reinforcing the statistical models by using other techniques and variables that allow analysing in-depth this phenomenon per regions (Agarwal et al. 2010). The second limitation is the lack of information 
about organisational variables (e.g., indicators associated with productivity and performance). We only have access to the cost associated with those social innovations. Therefore, we did not explore other indirect/direct effects or externalities produced by formal/ informal environmental conditions (Okereke et al. 2012). In this sense, another research venue could be explored corporate governance and responsibility issues behind those practices (De Bakker et al. 2005; Egri and Ralston 2008; Griffin and Prakash 2014) and organisational transformations to face institutional complexity (Greenwood et al. 2011). The third limitation is the proxy used to explore social innovations. A natural extension of this work could include novel theoretical/methodological approaches to understand the linkages between technology transfer and social innovation in similar contexts. We hope that the directions proposed in this research will inspire many colleagues to extend the understanding of: (a) the role of technology transfer in stimulating a new modality of social innovations developed by established enterprises for protecting/preventing the effects of violent events or wicked problems, and (b) the outcomes of these practices.

Acknowledgements The authors acknowledge the support from the Mexican National Institute of Statistics and Geography (INEGI's Microdata Lab) during the data analysis process. David Urbano acknowledges the financial support from the Spanish Ministry of Economy and Competitiveness [Project ECO2017-87885-P], the Economy and Knowledge Department—Catalan Government [Project 2017-SGR-1056] and ICREA under the ICREA Academia Programme.

Open Access This article is licensed under a Creative Commons Attribution 4.0 International License, which permits use, sharing, adaptation, distribution and reproduction in any medium or format, as long as you give appropriate credit to the original author(s) and the source, provide a link to the Creative Commons licence, and indicate if changes were made. The images or other third party material in this article are included in the article's Creative Commons licence, unless indicated otherwise in a credit line to the material. If material is not included in the article's Creative Commons licence and your intended use is not permitted by statutory regulation or exceeds the permitted use, you will need to obtain permission directly from the copyright holder. To view a copy of this licence, visit http://creativecommons.org/licenses/by/4.0/.

\section{References}

Agarwal, R., Audretsch, D., \& Sarkar, M. B. (2010). Knowledge spillovers and strategic entrepreneurship. Strategic Entrepreneurship Journal, 4(4), 271-283.

Aidis, R. (2005). Institutional barriers to small and medium-sized enterprise operations in transition countries. Small Business Economics, 25(4), 305-317.

Alvord, S. H., Brown, L. D., \& Letts, C. W. (2004). Social entrepreneurship and societal transformation: An exploratory study. The Journal of Applied Behavioral Science, 40(3), 260-282.

Audretsch, D. B., \& Feldman, M. P. (1996). R\&D spillovers and the geography of innovation and production. The American Economic Review, 86(3), 630-640.

Battilana, J., \& Dorado, S. (2010). Building sustainable hybrid organizations: The case of commercial microfinance organizations. Academy of Management Journal, 53(6), 1419-1440.

Baumol, W. J. (1990). Entrepreneurship: Productive, unproductive and destructive. Journal of Political Economy, 98(5), 893-921.

Bruton, G. D., Ireland, R. D., \& Ketchen, D. J. (2012). Toward a research agenda on the informal economy. The Academy of Management Perspectives, 26(3), 1-11.

Bunker, R. J. (2013). Introduction: the Mexican cartels-Organized crime vs. criminal insurgency. Trends in Organized Crime, 16(2), 129-137.

Byrne, J., \& Marx, G. (2011). Technological innovations in crime prevention and policing. A review of the research on implementation and impact. Journal of Policy Studies, 20(3), 17-40.

Chowdhury, F., Audretsch, D. B., \& Belitski, M. (2015). Does corruption matter for international entrepreneurship? International Entrepreneurship and Management Journal. https://doi.org/10.1007/s1136 5-015-0372-5. 
Coleman, R. (2003). CCTV surveillance, power and social order: The state of contemporary social control. In S. Tombs \& D. Whyte (Eds.), Researching the crimes of the powerful: The scrutinizing states and corporations (pp. 88-104). New York: Peter Lang.

Coleman, R., Tombs, S., \& Whyte, D. (2005). Capital, crime control and statecraft in the entrepreneurial city. Urban Studies, 42(13), 2511-2530.

Corman, H., \& Mocan, H. (2002). Carrots, sticks, and broken windows. NBER working paper no. 9061.

De Bakker, F. G., Groenewegen, P., \& Den Hond, F. (2005). A bibliometric analysis of 30 years of research and theory on corporate social responsibility and corporate social performance. Business and Society, 44(3), 283-317.

Demircioglu, M. A., \& Audretsch, D. B. (2018). Conditions for complex innovations: evidence from public organizations. The Journal of Technology Transfer. https://doi.org/10.1007/s10961-018-9701-5.

DiMaggio, P. J., \& Powell, W. W. (1983). The iron cage revisited: Institutional isomorphism and collective rationality in organizational fields. American Sociological Review, 48, 147-160.

Dowling, J., \& Pfeffer, J. (1975). Organizational legitimacy: Social values and organizational behavior. Pacific Sociological Review, 18, 122-136.

Duyne, P. C. (1996). Organized crime, corruption and power, crime. Law and Social Change, 20(3), 28-31.

Edwards, S. (2001). Capital mobility and economic performance: Are emerging economies different? No. w8076. National Bureau of Economic Research.

Egri, C. P., \& Ralston, D. A. (2008). Corporate responsibility: A review of international management research from 1998 to 2007. Journal of International Management, 14(4), 319-339.

Goel, R. K., \& Nelson, M. A. (2020). How do firms use innovations to hedge against economic and political uncertainty? Evidence from a large sample of nations. The Journal of Technology Transfer. https://doi. org/10.1007/s10961-019-09773-6.

Gould Ellen, I., \& O'Regan, K. (2008). Crime and urban fight revisited: The effect of the 1990s drop in crime on cities. Mimeo: New York University.

Greene, W. H. (2003). Econometric analysis. New York: Prentice-Hall.

Greenwood, R., Raynard, M., Kodeih, F., Micelotta, E. R., \& Lounsbury, M. (2011). Institutional complexity and organizational responses. The Academy of Management Annals, 5(1), 317-371.

Griffin, J. J., \& Prakash, A. (2014). Corporate responsibility: Initiatives and mechanisms. Business and Society, 53, 465-482.

Guerrero, M., Herrera, F., \& Urbano, D. (2019). Strategic knowledge management within subsidised entrepreneurial university-industry partnerships. Management Decision, 57(12), 3280-3300.

Guerrero, M., \& Urbano, D. (2019). Effectiveness of technology transfer policies and legislation in fostering entrepreneurial innovations across continents: An overview. The Journal of Technology Transfer, 44(5), 1347-1366.

Hausmann, R., Lozoya, E., \& Mia, I. (2009). The Mexico competitiveness report 2009. Geneva: World Economic Forum.

Heinle, K., Molzahn, C., \& Shirk, D. (2015). Drug violence in Mexico: Data and analysis through 2014. Special report: Justice in Mexico project. University of San Diego: Department of Political Science and International Relations. https://justiceinmexico.org/wp-content/uploads/2016/04/DrugViolen ceinMexico-Final-2015.pdf. Accessed 14 Dec 2018.

Hoskisson, R. E., Eden, L., Lau, C. M., \& Wright, M. (2000). Strategy in emerging economies. Academy of Management Journal, 43(3), 249-267.

Howard-Grenville, J., Buckle, S. J., Hoskins, B. J., \& George, G. (2014). Climate change and management. Academy of Management Journal, 57(3), 615-623.

INEGI. (2012). Encuesta Nacional de Victimización de Empresas. Síntesis Metodológica. Aguascalientes: Instituto Nacional de Estadística y Geografía.

Kan, P. R. (2011). What we're getting wrong about Mexico. Parameters, 41(2), 37-48.

Klapper, L., Amit, R., \& Guillén, M. F. (2010). Entrepreneurship and firm formation across countries. In J. Lerner \& A. Schoar (Eds.), International differences in entrepreneurship (pp. 129-158). Chicago: University of Chicago Press.

Lawrence, T. B., Hardy, C., \& Phillips, N. (2002). Institutional effects of interorganizational collaboration: The emergence of proto-institutions. Academy of Management Journal, 45(1), 281-290.

Lee, R. P., Özsomer, A., \& Zhou, K. Z. (2015). Introduction to the special issue on "innovation in and from emerging economies. Industrial Marketing Management, 50(October), 16-17.

Levitt, S. (2004). Understanding why crime fell in the 1990s: Four factors that explain the decline and six that do not. Journal of Economic Perspectives, 18, 163-190.

Link, A. N., \& Scott, J. T. (2019). The economic benefits of technology transfer from US federal laboratories. The Journal of Technology Transfer, 44(5), 1416-1426. 
Loayza, N. (1996). The economics of the informal sector: A simple model and some empirical evidence from Latin America. Carnegie-Rochester Conference Series on Public Policy, 45, 129-162.

Mair, J., \& Marti, I. (2009). Entrepreneurship in and around institutional voids: A case study from Bangladesh. Journal of Business Venturing, 24(5), 419-435.

Marti, I., Courpasson, D., \& Dubard Barbosa, S. (2013). Living in the fishbowl. Generating an entrepreneurial culture in a local community in Argentina. Journal of Business Venturing, 28(1), 10-29.

Mauro, P. (1998). Corruption and the composition of government expenditure. Journal of Public economics, 69(2), 263-279.

Mehlum, H., Moene, K., \& Torvik, R. (2002). Market-based extortion. Newsletter of the American political science association organized section in comparative politics, 13.

Meissner, D., Polt, W., \& Vonortas, N. S. (2017). Towards a broad understanding of innovation and its importance for innovation policy. The Journal of Technology Transfer, 42(5), 1184-1211.

Méon, P. G., \& Sekkat, K. (2005). Does corruption grease or sand the wheels of growth? Public Choice, 122(1-2), 69-97.

Messner, S. F., Rosenfeld, R., \& Karstedt, S. (2013). Social institutions and crime. In F. T. Cullen \& P. Wilcox (Eds.), The Oxford Handbook of Criminological Theory (pp. 405-423). Oxford: Oxford University Press.

Mexican Government. (2013). National planning of development 2013-2018. Mexico: Presidencia de la República. Retrieved October, 2015, from [http://pnd.gob.mx/wp-content/uploads/2013/05/PND.pdf].

Meyer, K. E., Estrin, S., Bhaumik, S., \& Peng, M. W. (2009). Institutions, resources, and entry strategies in emerging economies. Strategic Management Journal, 30(1), 61-80.

Morselli, C., \& Giguere, C. (2006). Legitimate strengths in criminal networks. Crime, Law and Social Change, 45(3), 185-200.

Mulgan, G. (2006). The process of social innovation. Innovations, 1(2), 145-162.

Nichter, S., \& Goldmark, L. (2009). Small firm growth in developing countries. World Development, 37(9), 1453-1464.

North, D. C. (1990). Institutions, institutional change and economic performance. New York: Cambridge University Press.

Okereke, C., Wittneben, B., \& Bowen, F. (2012). Climate change: challenging business, transforming politics. Business and Society, 51(1), 7-30.

Parker, S. C. (2011). Intrapreneurship or entrepreneurship? Journal of Business Venturing, 26(1), 19-34.

Peng, M. W. (2001). How entrepreneurs create wealth in transition economies. Academy of Management Executive, 15, 95-108.

Peng, M. W. (2003). Institutional transitions and strategic choices. Academy of Management Review, 28, 275-296.

Porter, M., \& Schwab, K. (2008). Global competitiveness report 2008-2009. Switzerland: World Economic Forum.

Ranasinghe, A. (2012). Property rights, extortion and the misallocation of talent. In 2012 meeting papers no. 293. Society for Economic Dynamics.

Rayner, S. (2006). Wicked problems: Clumsy solutions-diagnoses and prescriptions for environmental ills. Jack Beal Memorial Lecture on Global Environment.

Rittel, H., \& Webber, M. (1973). Dilemmas in a general theory of planning. Public Sciences, 4, 155-169.

Rodriguez, P., Uhlenbruck, K., \& Eden, L. (2005). Government corruption and the entry strategies of multinationals. Academy of Management Review, 30, 383-396.

Rosenthal, S. S., \& Ross, A. (2010). Violent crime, entrepreneurship, and cities. Journal of Urban Economics, 67(1), 135-149.

Ruggiero, V. (2010). Who corrupts whom? A criminal eco-system made in Italy. Crime, Law and Social Change, 54(1), 87-105.

Schweitzer, F., Rau, C., Gassmann, O., \& Hende, E. (2015). Technologically reflective individuals as enablers of social innovation. Journal of Product Innovation Management, 32(6), 847-860.

Scott, W. R. (1995). Institutions and organizations. Newbury Park, CA: Sage.

Scuotto, V., Del Giudice, M., \& Carayannis, E. G. (2017). The effect of social networking sites and absorptive capacity on SMES' innovation performance. The Journal of Technology Transfer, 42(2), 409-424.

Smallbone, D., \& Welter, F. (2006). Institutional development and entrepreneurship in a transition context. International research in the business disciplines. In C. Galbraith \& C. Stiles (Eds.), Development entrepreneurship: Adversity, risk, insolation (p. 37). Oxford: Elsevier.

Sobel, R. S. (2008). Testing Baumol: Institutional quality and the productivity of entrepreneurship. Journal of Business Venturing, 23(6), 641-655. 
Solleiro, J. L., \& Castañón, R. (2005). Competitiveness and innovation systems: The challenges for Mexico's insertion in the global context. Technovation, 25(9), 1059-1070.

Stenholm, P., Acs, Z. J., \& Wuebker, R. (2013). Exploring country-level institutional arrangements on the rate and type of entrepreneurial activity. Journal of Business Venturing, 28(1), 176-193.

Subramaniam, M., Ernst, H., \& Dubiel, A. (2015). From the special issue editors: Innovations for and from emerging markets. Journal of Product Innovation Management, 32(1), 5-11.

Vaccaro, A., \& Palazzo, G. (2015). Values against violence: Institutional change in societies dominated by organized crime. Academy of Management Journal, 58(4), 1075-1101.

Van Wijk, J., Van der Duim, R., Lamers, M., \& Sumba, D. (2015). The emergence of institutional innovations in tourism: The evolution of the African Wildlife Foundation's tourism conservation enterprises. Journal of Sustainable Tourism, 23(1), 104-125.

Webb, J. W., Tihanyi, L., Ireland, R. D., \& Sirmon, D. G. (2009). You say illegal, I say legitimate: Entrepreneurship in the informal economy. Academy of Management Review, 34(3), 492-510.

Weber, M. (1978). Economy and society: An outline of interpretive sociology. Berkeley, CA: University of California Press.

Welter, F., \& Smallbone, D. (2011). Institutional perspectives on entrepreneurial behaviour in challenging environments. Journal of Small Business Management, 49(1), 107-125.

Williams, P., \& Godson, R. (2002). Anticipating organized and transnational crime. Crime, Law and Social Change, 37(4), 311-355.

Witkamp, M. J., Raven, R. P., \& Royakkers, L. M. (2011). Strategic niche management of social innovations: The case of social entrepreneurship. Technology Analysis \& Strategic Management, 23(6), $667-681$.

Wright, M., Filatotchev, I., Hoskisson, R. E., \& Peng, M. W. (2005). Strategy research in emerging economies: Challenging the conventional wisdom. Journal of Management Studies, 42(1), 1-33.

Wu, X. (2005). Corporate governance and corruption: A cross-country analysis. Governance: An International Journal of Policy, Administration and Institutions, 18(2), 151-170.

Zietsma, C., \& Lawrence, T. B. (2010). Institutional work in the transformation of an organizational field: The interplay of boundary work and practice work. Administrative Science Quarterly, 55, 189-221.

Zimmerman, M. A., \& Zeitz, G. J. (2002). Beyond survival: Achieving new venture growth by building legitimacy. Academy of Management Review, 27, 414-431.

Publisher's Note Springer Nature remains neutral with regard to jurisdictional claims in published maps and institutional affiliations. 